\title{
IMPACT OF OPERATING COSTS ON ECONOMIC PHENOMENA AND THE POSSIBILITY OF THEIR OPTIMIZATION AT PROCESSORS
}

\author{
Nataliya Bondarchuk ${ }^{1}$, Lesya Vasiljeva ${ }^{2}$ \\ Dnipropetrovsk State Agrarian and Economic University, Ukraine
}

\begin{abstract}
In conditions of self-repayment and self-financing, the profit maximization and production efficiency increase become the main aim of enterprises. Under the impact of deflationary conditions and many other reasons, the prices fixation at a certain level is necessary for the maintenance of the effectual demand and supply. In this case, the effective system of production costs management becomes necessary for the maintenance of profitability level and reaching the high indicators of enterprise operations. The forecasting of leading economic indicators is an important operations direction of any sphere in modern economic conditions. The aim of this article is to research the impact of costs on the economic phenomena of enterprises of processing sphere and give the opportunity for their optimization. The theoretic, methodical, and application issues relating to the management of costs and their optimization at enterprises of processing sphere are the goal of the research. Methodology. In the article writing, the following methods were used: abstract-logical, monographic, economic and mathematical. Results. The enterprise costs are not only an indicator of its profitability determination, and an indicator, with the help of which there is a possibility to determine the enterprise's development level as well. It is stated that the basic mechanism of processing industry enterprises operation is a management system, and the costs management is one of the main functions of it. The development of measures for the production costs decrease is the main element of the costs management system at the enterprise. The search for suppliers of the reliable operating resources; manufactured products variety improvement; labour organization and selling improvement; labour efficiency increase; maximum involvement of additional income and available assets (lease of areas, not currently used by the business entity that will result in additional income and, thus, reduce the cost of maintenance of these premises or equipment); permanent control over the enterprise's costs; increase of efficiency of internal costs management, basing the timely and qualitative analysis are used for the purpose of optimization of the operational costs at enterprises of processing industry. Practical implications. The multicriteria optimization model of enterprise costs has been developed for the costs management at the enterprises of the processing industry. Its essence is to find the optimal plan for the production of sausage products and the volume of renewal of production resources in the conditions of limitation of production costs. The implementation of this model consists from three stages: 1) the volumes of production of sausage products, subject to search, are determined by the variables, with dual indexation; 2 ) the restrictions for the created model are determined; 3 ) the target functions of the created model are determined. Value/originally. The optimization of production costs and management of the output plan of the meat processing and packing plant products allows the provision of a rational structure of meat products and form the volumes of their renewal with the resources during the minimization of the deviation of a new production plan relative to current one.
\end{abstract}

Key words: production costs, enterprises of processing industry, costs optimization, optimization model.

JEL Classification: C53, M11, M21

\footnotetext{
Corresponding author:

${ }^{1}$ Department of Accounting, Audit and Financial and Economic Safety Management, Dnipropetrovsk State Agrarian and Economic University.

E-mail: bondarchuk-nv@ukr.net

${ }^{2}$ Department of Accounting, Audit and Financial and Economic Safety Management, Dnipropetrovsk State Agrarian and Economic University.

E-mail: bondarchuk-nv@ukr.net
} 


\section{Introduction}

The forecasting of the main economic indicators is an important direction of the activity of any sphere in modern economic conditions. The degree of use of labour, material and other resources is crystallized in the enterprise costs. Their amount is featured by the results of materialized economic relations of production entities, acting independently at their discretion according to the economic interests.

In current conditions, the production costs cannot be considered as only technical and economic, and accounting categories already. The consistency and separate economic laws are demonstrated in amount, structure, time-space of costs. In particular: of timesaving, labour efficiency increase, distribution by the results of materialized and living labour and others.

The production costs are the subject of important and continuous care in the theory of reproduction, as they relate directly to the production practice, are aimed at its specific analysis and the development of recommendations for managers and teams. As a result, the issues of optimization of production costs at the micro level become of particular importance.

The research of the impact of costs on economic phenomena of enterprises of processing industry and the opportunity of their optimization bringing are the aims of this article.

The theoretic, methodical, and application issues regarding the costs management and their optimization at the enterprises of processing industry are the subject of research.

The observing the changes and research of production costs, timely determination of their level is one of the reliable channels for competition in a market economy's analysing. After all, entrepreneurship is not only creativity for the creation of consumer goods but also persistent, purposeful management of the resources of the production subjects.

Therefore, disclosing the content of this research, it is necessary to determine the economic content of costs first and their impact on the economic phenomena, to consider the possible ways of optimization of enterprises production costs of the processing industry, and we will develop the multicriteria optimization model of enterprises production costs of the processing industry.

\section{The essence of production costs and their impact on economic phenomena}

Production costs are a complex multilateral phenomenon that can be considered from different sides. The production costs are divided into the social costs and the enterprise costs from the standpoint of socio-economic relations. From the point of view of society, the costs include all living and materialized labour, which obtain the form of price of finished goods and form the price structure of a social product. The latter is one of the most important problems in the research of social reproduction.

The production costs of a separate manufacturer are the payments to the resources owners (means of production, labour) carried out by the business entity in order to attract them to its production. The costs include the cost of raw materials, materials, components, services, and other material resources, the cost of wages for the production of finished goods. It is necessary to emphasize that costs are the resources spending, which has obtained the price form in the competitive market. That is why the economic understanding of the production costs is based on the fact of the exclusivity of resources and the possibility of their alternative use. The economic costs of any resource, used to produce a product, are equal to its price at the best of all alternative uses. They can be external (explicit) and internal (implicit). Explicit costs, associated with payments to suppliers of production factors, the purchase of resources from outside parties.

There are many concepts of production costs. In his time, A. Smith introduced the concept of absolute costs (Smith, 2007), and D. Ricardo became the author of the theory of comparative advantages (Ricardo, 1995). They meant the public average costs per unit of output as a term "costs". The costs are also defined as the price of production, taking into account rental payments.

According to the Marxist theory, the production costs are the amount of the goods value to the capitalist that is the amount of his costs for the purchase of means of production and labour. Criticizing A. Smith, K. Marx noted "... A. Smith has one-sided interpretations of the social product or the position of certain labour (in this case, the annual public product acted as the whole amount of produced in a year of use values) or from the side of abstract labour (from this point, the public product was meant by Smith as a newly created value)" (Marx, 1983).

At the end of the XIX century, new concepts of costs appeared. Marginists consider costs as a phenomenon, based on marginal utility (Menger, Wieser, 1992). The amount paid by the enterprise for the factors of production is determined by the marginal utility they have on behalf of the seller.

The transition to the mathematical basis of the concept of the theory of alternative possibilities, according to which the actual production costs are the greatest utility of the benefits that society could receive in the case when it used the spent resources in the other way, contributed to the emergence of the theory of costs minimization.

In addition to the theory of marginal utility of costs in the economy, the institutional theory of costs is also met. It is represented in the works of J.B. Clark. In a due time, the theory of transaction costs, associated with the turnover (costs for the sale of goods, advertising, etc.) became popular (Clark, 1992). R. Coase (Coase, 2000) is considered the founder of this theory. 
The concept of costs in the work of J. M. Keynes "The General Theory of Employment” became widely known. In his work, the author distinguishes the following value elements of the product: a) the use costs; b) factorial costs; c) additional costs; d) total income of enterprises (Keynes, 1978).

M. Tugan-Baranovskiy was the first who has combined the labour and consumer theories of value in the Ukrainian economic literature. The concept "value", as a result of costs of means and products, and "labour value", as a result of the living labour expenses, was introduced (Tugan-Baranovskiy, 2003).

The formation of the enterprise costs can be both extensive and intensive. Extensive costs formation focuses on attracting the additional resources. The intensification provides that the production results increase faster than costs. That is, the production involves relatively fewer resources in order to obtain more significant results. Thus, the main task of the degree of production intensification analysis is the search for reserves of the extensive and intensive level of costs formation and, as a result, a decrease of production costs.

In fact, there cannot be only intensive and extensive type of development. It will be more correct to talk about a predominantly intensive or predominantly extensive type of development. A certain increase in efficiency and cost reduction may be available also in predominantly extensive type.

The intensification of all resources use, providing the decrease of production costs in the processing of agricultural products industry, depends on the solution of two interrelated problems:

- the search and rational use of financing amounts regarding the creation of new powers, more efficient labour instruments, renewal and technical upgrade of capabilities;

- the intense use of available resources and improvement of this process management mechanism.

More complete and rational use of resources and production powers of agricultural products processing industry will assist in the improvement of all its technical and economic indicators, an increase of labour efficiency, the yield on capital investments increase.

The economic activity run by economic entities in current market conditions has led to a radical rethinking of content, methods, and tools for costs formation. In the new conditions of enterprises functioning, it is necessary to include a charge for compulsory medical insurance, payments for insurance of means of production, life and health of employees, other insurance contributions to costs. In conditions when the entrepreneurs become business entities, to our mind, the costs should include a part of the profit, which makes insurance contributions of entrepreneurial income.

In addition to the economic approach to determining the costs of an enterprise, there is also a so-called accounting approach, according to which costs should be understood as actually consumed production factors for the production of a certain number of products at the prices of their purchase. The costs are considered as the products cost in the accounting and statistical reporting documents.

The systems of costs formation in the accounting approach are featured by two main indicators, which can be used as the basis of their classification:

1. By the completeness of the costs inclusion to the products costs:

- complete costs accounting system - the traditional system, according to which the total amount of costs is related to objects of calculation, and thus their full cost is determined;

- incomplete costs accounting system - in this case, only a part of total costs by aby feature ("direct-costing") is related to the calculation objects.

2. By degree of costs rate setting:

- the system of accounting of actual costs provides the representation of business processes and costs, incurred during the accounting period;

- normative-planned cost accounting system provides planning of future enterprise costs, based on current norms and fixing deviations of actual costs from the planned ("standard-cost") (Druri, 1998; Golov, 2004).

\section{Directions of optimization of production costs of processing industry enterprises}

Lack of due management of all production resources at the enterprise almost always leads to a crisis in those cases, when most of the resources are spent for current consumption, payment of debts and interest on them. Each separate enterprise cannot maintain its position in markets for a long time with such financial indicators. Management of production costs, in this case, should be directed to the increase of the production efficiency through the use of high-tech and resource-saving technologies.

As a rule, the production activity of the processing industry enterprises has a continuous nature and is accompanied by the presence of uncompleted production at the end of the calculation period. The amount of permissible and necessary volume of uncompleted production is calculated taking into account the length of the production cycle of the output and the type of production. In this case, the main task of cost formation is the determination and counting of all factors, at which the set volume of production will be produced with minimal cost.

The basic mechanism of operation of enterprises of the processing industry is a management system, one of the main functions of which is cost management. The cost of an enterprise is not only an indicator for determining its profitability but also an indicator that allows us to assess the level of enterprise development, 
the structure and range of production opportunities, etc. (Bedrinets, 2013).

The costs of the enterprise are the basis for the formation of its profits, and in current market conditions, the operation of the processing industry enterprise is impossible without a system of costs planning and control. The goal of the analysis of the activities costs of such enterprises is to comprehensively assess the actual data, their optimization and management decisions explanation for further rationalization. Analysis can be based on the principles of the system, complex, and cybernetic approaches:

An important component of the cost management system at the enterprise is the development of measures to reduce the production cost, which, in the further research, will be shown on the example of the enterprises of the processing industry.

In order to optimize operating costs in the processing industry, you can use the following measures:

- search for reliable suppliers of productive resources;

- improvement of the range of products;

- improvement of the organization of labour and marketing activities;

- increase in labour productivity;

- maximal attraction of additional income from free assets (lease of areas that are not currently used by the business entity, which will bring additional income and, thus, reduce the cost of maintaining these premises or equipment);

- permanent control over the expenses of the enterprise;

- increasing the efficiency of internal cost management based on the timely and qualitatively conducted analysis (Prisyazhnyuk, 2016).

One of the directions of optimization of production costs is the application of economic and mathematical models of monitoring management of replenishment of resources and production plan.

\section{Research methodology}

In order to optimize the costs of the processing industry enterprises, we suggest the following methodology and the economic-mathematical model of the monitoring management of replenishment of resources and the plan for producing meat products, which has the appearance of a multicriteria optimization task.

The resources, necessary for the production of meat products will be classified according to the following types:

- raw materials;

- technical (equipment, parts for its repair, structures);

- power (electricity, fuel);

- labour (employees by level of qualification);

- financial (own funds of the meat processing and packing plant and loans for the purchase and payment of the said resources for sale of manufactured products).
Let us relatively limit the scope of the meat processing and packing plant by the manufacture of 14 types of sausage products that the meat processing and packing plant can produce: stuffed, boiled sausages, sausages, bockwurst, meat loaves, liver, blood sausages, pastes, saltisons, chillies, semi-smoked, boiled smoked, smoked and dried sausages (Rogov, Zabashta, Kazulin, 2000).

According to (Rogov, Zabashta, Kazulin, 2000), the raw material for sausages is meat (mainly beef and pork); by-products (beef and pork lungs, liver, heart, kidneys, brains, etc.); blood products; protein preparations of animal origin; soy supplements; spin and other animal and vegetable fats; eggs; wheat flour; groats; salting ingredients (salt, sugar, sodium nitrate); spicy flavouring mixes. The raw materials also include the shell for sausage products, which is natural (intestinal) and artificial.

We also understand the technical equipment of the meat processing and packing plant:

- the equipment for receiving raw materials (mechanisms for unloading of transport, weighing equipment, hanging conveyors, floor wheel transport); - equipment for the preparation of meat raw material for industrial processing (washing machines, carcasses, conveyors for rolling and hulling of meat, machines for removing skins from spits, spit coolers);

- equipment for cutting, salting, and maturation of meat (choppers, machines for crushing of frozen blocks, cutting of spoke, mixers for meat salting, units for crushing, equipment for maturation of meat);

- currently mechanized production line of sausage products:

- equipment for making minced meat (mixers, shredders, cutters, colloid mills);

- equipment for the production of sausage products (screw syringes, eccentric-shovel-shaped, and piston machines; transwraps and units for production of sausages in cutting shells; pentaflex, belkosin, cellophane; machines for making sausage products with the formation of vesicant cellophane and sleeve cover; units for binding and bracing of bars);

- heat treatment equipment (smoke generators, rotary ovens, cooking boilers and cabinets);

- equipment for storage of finished products for dispatch (storage units, containers, mechanized expedition).

Monitoring, as a systematic observation of changes in the market environment in the sphere of meat products manufacture, will reflect random current fluctuations (possibly due to known probabilities) of factors of production and sales of sausage products, namely:

- the cost of the listed raw materials;

- the costs of replenishing technical and energy resources;

- the cost of finished products;

- interests in attracting the additional financial resources; 
- signed contracts for the supply of certain meat products.

It is necessary to emphasize for each of the listed resources:

- available volumes;

- unknown amounts of replenishment of resources, the search of which is an integral part of the solution goal of this task;

- current costs of the units of the volume of replenished resources in accordance with market monitoring data.

Let us assume that the meat processing and packing plant is provided with a data block relating to:

- current range and volumes of finished meat products; - the cost of changes in the production plan (by attracting the additional or dismissed redundant employees, setting up new lines, adapting the equipment, refusing from raw material suppliers services, conducting promotional campaigns of new products, additional monitoring analysis of the products consumers market, the establishment of new contacts in the trading network).

Moreover, according to monitoring data, there are known:

- list of current selling prices of meat products in the consumption market;

- the cost of producing units of this product at this meat processing and packing plant.

The goal of the production activity of the meat processing and packing plant may be subject to various criteria, the list of which may include:

- reduction of total cost of finished goods at the expense of minimization of costs of production resources;

- maximization of profits from the sale of meat products;

- minimization of the deviation of the developed production plan from the current one;

- reduction of costs for replenishment of production resources;

- improving the quality of production, which can be estimated by increasing the profit from higher grades products, from environmentally friendly, nontransgenic products, in attractive packaging, etc.

So, it is necessary to find the optimal plan for the production of sausage products and the amount of replenishment of resources in order to satisfy the listed criteria, in the conditions of limiting the production costs for the corresponding resources and executing orders for certain products of the meat processing and packing plant.

Note that in general, there will be no plan for the production of sausage products in the meat processing and packing plant, which simultaneously meets all listed criteria. Therefore, we will be interested in finding a set of so-called unimproved plans. Taking into account all the above, we will develop a model of the described economic problem of processing of agricultural products in the form of a multi-criteria optimization task. The implementation of this model consists of three stages.

I stage. The volumes of production of sausages products, which are subject to search, are determined by variables, with double indexation.

II stage. The restrictions for the developed model are determined. Before describing the restrictions of the developed model, we define some parameters and coefficients related to the previous results of the meat processing and packing plant operation and the data of the current monitoring observations. The restrictions of the developed model will not give the opportunity to spend more resources in the production process, than their available and replenished volumes, as well as the mandatory nature of the execution of orders for certain types of sausage products. The main restrictions include: raw materials, technical, energy, labour, financial resources, and custom-made restrictions.

III stage. Determination of the target functions of the developed model.

Thus, the economic-mathematical model of the monitoring management of replenishment of resources and production plan at the meat processing and packing plant acquires the finished form of such a multi-criteria optimization problem:

find:

$x_{i j}, j=1 . . j_{i}, i=1 . .14$, and $y_{k q}, q=1 . . q_{k}, k=1 . .5$,

At which:

$\sum_{i=1 . .14} \sum_{j=1 . . j_{i}} c_{i j} x_{i j} \rightarrow \min$,

$\sum_{i=1.14} \sum_{j=1 . . j_{i}}\left(b_{i j}-c_{i j}\right) x_{i j} \rightarrow \max$,

$\sum_{i=1.14} \sum_{j=1 . . j_{i}} w\left(\tilde{x}_{i j}\right)\left(x_{i j}-\tilde{x}_{i j}\right)^{2} \rightarrow \min$

(or $\left.\sum_{i=1.14} \sum_{j=1 . . j_{i}} w\left(\tilde{x}_{i j}\right)\left|x_{i j}-\tilde{x}_{i j}\right| \rightarrow \min \right)$,

$\sum_{k=1 . .5} \sum_{q=1 . . q_{k}} d_{k q} y_{k q} \rightarrow \min$,

$\sum_{i=1 . .14} \sum_{j=1 . . j_{i}} s_{i j} b_{i j} x_{i j} \rightarrow \max$

Are reached at restrictions:

$\sum_{i=1 . .14} \sum_{j=1 . . j_{i}} a_{i j}^{k q} x_{i j} \leq Y_{k q}+y_{k q}, q=1 . . q_{k}, k=1 . .5,(6)$

$x_{i j} \geq Z_{i j}, j=1 . . j_{i}, i=1 . .14$,

$x_{i j} \geq 0, j=1 . . j_{i}, i=1 . .14$,

$y_{k q} \geq 0, q=1 . . q_{k}, k=1 . .5$,

$y_{k q}, q=1 . . q_{k}, k=2,4-$ integral values.

To solve the problem (1)-(10), the linear convolution of its criteria with positive weighing factors should be used $\alpha_{1}, \ldots, \alpha_{5}$, where $\sum_{m=1 . .5} \alpha_{m}=1$, that is, to move from the model (1)-(10) to the parametric singlecriterion optimization problem:

find:

$x_{i j}, j=1 . . j_{i}, i=1 . .14$, and $y_{k q}, q=1 . . q_{k}, k=1 . .5$, at which:

$\alpha_{1}\left(\sum_{i=1.14} \sum_{j=1 . . j_{i}} c_{i j} x_{i j}\right)-\alpha_{2}\left(\sum_{i=1.14} \sum_{j=1 . . j_{i}}\left(b_{i j}-c_{i j}\right) x_{i j}\right)+$ $+\alpha_{3}\left(\sum_{i=1 . .14} \sum_{j=1 . . j_{i}} w\left(\tilde{x}_{i j}\right)\left(x_{i j}-\tilde{x}_{i j}\right)^{2}\right)+$ 


$$
\begin{aligned}
& +\alpha_{4}\left(\sum_{k=1 . .5} \sum_{q=1 . . q_{k}} d_{k q} y_{k q}\right)- \\
& -\alpha_{5}\left(\sum_{i=1 . .14} \sum_{j=1 . . j_{i}} s_{i j} b_{i j} x_{i j}\right) \rightarrow \min \\
& \left(\text { or } \alpha_{1}\left(\sum_{i=1 . .14} \sum_{j=1 . . j_{i}} c_{i j} x_{i j}\right)-\alpha_{2}\left(\sum_{i=1 . .14} \sum_{j=1 . . j_{i}}\left(b_{i j}-c_{i j}\right) x_{i j}\right)+\right. \\
& +\alpha_{3}\left(\sum_{i=1 . .14} \sum_{j=1 . . j_{i}} w\left(\tilde{x}_{i j}\right)\left|x_{i j}-\tilde{x}_{i j}\right|\right)+ \\
& \left.+\alpha_{4}\left(\sum_{k=1 . .5} \sum_{q=1 . . q_{k}} d_{k q} y_{k q}\right)-\alpha_{5}\left(\sum_{i=1 . .14} \sum_{j=1 . . j_{i}} s_{i j} b_{i j} x_{i j}\right) \rightarrow \min \right)
\end{aligned}
$$

Is reached at restrictions (6)-(10).

It should be noted that the equivalent record to (11) has a form:

$$
\begin{aligned}
& -\alpha_{1}\left(\sum_{i=1 . .14} \sum_{j=1 . . j_{i}} c_{i j} x_{i j}\right)+\alpha_{2}\left(\sum_{i=1 . .14} \sum_{j=1 . . j_{i}}\left(b_{i j}-c_{i j}\right) x_{i j}\right)- \\
& -\alpha_{3}\left(\sum_{i=1 . .14} \sum_{j=1 . . j_{i}} w\left(\tilde{x}_{i j}\right)\left(x_{i j}-\tilde{x}_{i j}\right)^{2}\right)- \\
& -\alpha_{4}\left(\sum_{k=1 . .5} \sum_{q=1 . q_{k}} d_{k q} y_{k q}\right)+\alpha_{5}\left(\sum_{i=1 . .14} \sum_{j=1 . . j_{i}} s_{i j} b_{i j} x_{i j}\right) \rightarrow \max \\
& \left(\operatorname{or}-\alpha_{1}\left(\sum_{i=1 . .14} \sum_{j=1 . . j_{i}} c_{i j} x_{i j}\right)+\alpha_{2}\left(\sum_{i=1 . .14} \sum_{j=1 . . j_{i}}\left(b_{i j}-c_{i j}\right) x_{i j}\right)-\right. \\
& -\alpha_{3}\left(\sum_{i=1 . .14} \sum_{j=1 . . j_{i}} w\left(\tilde{x}_{i j}\right)\left|x_{i j}-\tilde{x}_{i j}\right|\right)- \\
& \left.-\alpha_{4}\left(\sum_{k=1 . .5} \sum_{q=1 . q_{k}} d_{k q} y_{k q}\right)+\alpha_{5}\left(\sum_{i=1.14} \sum_{j=1 . . j_{i}} s_{i j} b_{i j} x_{i j}\right) \rightarrow \max \right)
\end{aligned}
$$

The Excel table (a part of the application programs of Microsoft Office) is a convenient way to solve the problem (6)-(10), (11).

In the economic sense, the parameters $\alpha_{1}, \ldots, \alpha_{5}$ will set different weights of criteria (1)-(5) according to the needs of the meat processing and packing plant under the conditions of the current state of the meat products market according to monitoring observations, which will allow searching for unimproved plans for the production of sausages products and the amount of replenishment of their resource support.

\section{Findings}

The production costs optimization and the management of the products output plan of the meat processing and packing plants can provide a rational structure of meat products and to form the volumes of their replenishment with resources during the minimization of deviation of a new production plan from the current one. The value $C_{i j}$ - the price of a unit of weight of sausage products of the $i$-type of $j$-name. Therefore, the criterion (1) is associated with minimization of total costs for the production of sausage meat products. The value $b_{i j}$ - is a current market price of selling of the unit of the weight of sausage products of $i$-type of $j$-name. That is why the criterion (2) is intended for the search for the maximum profit from selling sausage products. The coefficient $\tilde{\mathcal{X}}_{i j}-$ is a known current volume of products manufacturing of $i$-type of $j$-name, and $w\left(\tilde{x}_{i j}\right)$ - set money costs of the meat processing and packing plant for the change for a unit of weight of the current plan of sausage products production of $i$-type of $j$-name. Then the target function (3) is associated with the minimization of deviation of new production plan of meat processing and packing plant from the previous one. The deviation $d_{k g}$-is a current cost of the resource replenishment of $k$-type of g-name per the unit of volume. Then, the target function (4) sets the minimum costs for the resource supply of sausage production of this meat processing and packing plant. The parameter $s_{i j}$ is featured by grade and qualitative features of the sausage products. That is why the criterion (5) is associated with the maximization of profit from the sale of high-quality sausage products of higher grades.

In restrictions $(6),(7)$ the value $Y_{k g}$ - sets the current volumes of resources of $k$-type of $g$-name, $a_{i j}^{k g}$ - resources expenses of $k$-type of $g$-name for the production of a unit of weight of sausage products of $i$-type of $j$-name, $Z_{i j}$ - the volumes of order for the $i$-type of $j$-name.

Applied calculations by the model (1)-(10) can be carried out in the framework of Microsoft Excel electronic table.

This method takes into account the maximum use of available resources and the ability of modern computers and allows getting the planned values of production costs.

\section{Conclusions}

It was established that production costs are a complex multilateral phenomenon that can be considered from different sides. The basic mechanism of operation of enterprises of the processing industry is the control system, one of the main functions of which is cost management. Enterprise costs are not only an indicator for determining its profitability but also an indicator that allows us to assess the degree of enterprise development, the structure and range of production opportunities, etc. Costs of production from the standpoint of socioeconomic relations are divided into the costs of society and the cost of the enterprise. From the point of view of society, costs include all living and materialized labour, which obtains the form of price of finished goods and forms the value structure of a social product. The latter is one of the most important problems in the study of social reproduction or the reimbursement of a product in both natural and material and cost forms.

In order to optimize the operating costs of enterprises in the processing industry, use:

- search for reliable suppliers of production resources;

- improvement of the assortment of products;

- improvement of the labour organization and marketing activities;

- increase in labour productivity;

- maximal attraction of additional profit from free assets (lease of areas that are not currently used by the entity, which will cause additional profit and, thus, reduce the cost of maintaining these premises or equipment);

- permanent control over the expenses of the enterprise;

- increase in the efficiency of internal cost management based on the timely and qualitatively conducted analysis. 
In order to optimize costs in processing industry enterprises, a methodology and economic and mathematical model of the monitoring management of replenishment of resources and a plan for producing of meat products, which has the form of a multicriteria optimization problem, have been developed.

The implementation of this model consists of three stages: 1) determine the volume of production of sausage products, which is subject to search, by dual indexation; 2) determine restrictions for the developed model; 3) determine target functions of the developed model.

Optimization of production costs and management of the output plan of the meat processing and packing plant can provide a rational structure of meat products and form volumes of renewal of their resources while minimizing the deviation of a new production plan from the current one.

\section{References:}

Bedrinets, M.D. (2013) Efektivnist diyalnosti subektiv pidpriemnitstva v suchasnikh umovakh gospodaryuvannya [Efficiency of activity of subjects of entrepreneurship in modern economic conditions]. Business Inform, no. 4, pp. 183-190 (in Ukrainian).

Coase, R.G. (2000) Priroda firmi. [Nature of the firm]. St.Petersburg: Economic school (in Russian).

Druri, K. (1998) Vvedenie v upravlencheskiy i proizvodstvenniy uchet. [Introduction to management and production accounting]. Moscow: Izdatelskoe obedinenie «YuNITI» (in Russian).

Golov, S.F. (2004) Upravlinskiy oblik. [Management Accounting]. Kiyv: Libra (in Ukranian).

Keynes, J.M. (1978) Obshchaya teoriya zanyatosti protsenta $i$ deneg. [General theory of employment of interest and money]. Moscow: Progress (in Russian).

Clark, J.B. (1992) Raspredelenie bogatstva [Distribution of wealth]. Moscow: Economika (in Russian).

Marx, K. (1983) Kapital. Kritika politicheskoj ekonomii: (Protsess proizvodstva kapitala). [Capital. Critique of political economy [the production Process of capital]. Moscow: Politizdat (in Russian).

Middlton, D. (1997) Bukhgalterskiy uchet i prinyatie finansovykh resheniy. [Accounting and financial decision making]. Moscow: Izdatelskoe obedinenie «YuNITI» (in Russian).

Prisyazhnyuk, L.G. (2016) Optimizatsiya vitrat pidpriemstv mashinobudivnoi galuzi za dopomogoyu informatsiynikh tekhnologiy ta optimizatsii upravlinnya zapasami [Optimization of the costs of machinery and equipment for the additional use of information technology and optimization of inventory management]. Investments: practice and experience, no. 20, pp. 76-79 (in Ukrainian).

Smith, A. (2007) Issledovanie o prirode i prichine bogatstva narodov [An inquiry into the nature and cause of the wealth of Nations]. Moscow: Eksmo\&Press (in Russian).

Ricardo, D. (1995) Stati i rechi o denezhnom obrashcheni i bankakh. [Articles and speeches on monetary circulation and banks]. Moscow: Gaspolitizdat (in Russian).

Rogov, I.A., Zabashta, A.G. Kazulin, G.P. (2000) Obshchaya tekhnologiya myasa i myasoproduktov. [General technology of meat and meat products]. Moscow: Kolos (in Russian).

Tugan-Baranovskiy, M. (2003) Osnovi polinichnoi ekonomii. [The basis of the political economy]. Lviv: Vid. Centr LNU im. Ivana Franka (in Ukrainian).

Wieser, F. Menger, K. Bem. E. (1992) Teoriya obshchestvennogo khozyaystva. [A theory of social economy] Moscow: Economics (in Russian). 